\title{
Neo-lamarckism și neo-darwinism ${ }^{\dagger}$
}

\author{
L.H. Bailey
}

Ipoteza evoluției organice este dificil de acceptat în abstract. În primul rînd, trebuie să existe un motiv ca o lege a transformării sau a evoluției să funcționeze, iar acesta se află în continua schimbare a condițiilor existenței fizice sau externe, ceea ce este mai mult sau mai puțin contrar organismelor stabilizate. De asemenea, se poate spune că tocmai sporirea organismelor pe calea înmulțirii impune noi condiții concurențiale fiecărei generații care se succede. Încă o dată, este necesar să se conceapă niște mijloace sau structuri prin care procesul evoluției să fie dus mai departe. Era de mult timp cunoscut că fiecare specie variază, că, adică, în natură nu există doi indivizi identici; cu toate acestea, lipsea o ipoteză care să arate de ce apar aceste variaţii, sau cum se întîmplă ca unele dintre acestea să devină permanente, iar altele nu. Prima explicație științifică a procesului evoluției a fost concepută în 1809 de către de acum faimosul Lamarck. Acesta a observat doi factori care, considera el, erau implicați în transformarea speciilor-habitatul și habitudinea. Mediul, subiect al schimbării pe calea oricărui nou individ, solicită noi deprinderi pentru a adapta organismul noilor nevoi-inducînd un exerciţiu sporit al anumitor capacități sau organe și un exerciţiu redus al altora. Acest uz, mai intens sau mai scăzut, întărește sau slăbește treptat organul respectiv, iar modificările astfel dobîndite sînt păstrate „pe calea eredității la noii indivizi, ei fiind produsul acestora-înţelegîndu-se că schimbările sînt comune celor două sexe-sau la cei care au produs acești noi indivizi”. Sînt trei lucruri ce trebuie luate în seamă la această ipoteză: 1. Schimbările din mediu sau de la nivelul condițiilor de viață acționează asupra organismelor în direcția nevoilor acestora sau a funcțiunilor. 2. Organele sau capacitățile astfel influențate se modifică spre a satisface noile solicitări. 3. Modificările dobîndite de către indivizi sînt ereditare. Acesta este, aşadar, lamarckismul: factorul de control sau procesul în evoluție este funcțional, trăsăturile dobîndite fiind lesne transmisibile. Este important să tot repet credința lui Lamarck în transmiterea unei trăsături dobîndite de către orice individ de-a lungul vieții sale, acesta fiind punctul de plecare al definiției unei „trăsături dobîndite” privind ereditatea, care divizează lumea științifică actuală. „Toate cele provocate indivizilor de către natură, pentru a dobîndi sau a pierde pe calea influenței circumstanțelor la care rasa lor a fost mult timp expusă”, spune Lamarck, „se păstrează” etc. Și iarăși: „Fiecare schimbare dobîndită la nivelul unui organ printr-un exercițiu obișnuit, petrecut îndeajuns încît să provoace acea schimbare la nivelul acelui organ, se păstrează ulterior pe calea eredității” etc. Trebuie să observăm în ce măsură au păstrat filozofii din vremea noastră această definiție a unei trăsături dobîndite.

La doar cincizeci de ani de la publicarea teoriei lui Lamarck, Darwin a propus o ipoteză care a avut o mai mare influență asupra deprinderilor gîndirii științifice decît orice afirmație făcută de la apariția filozofiei inductive. Precum Lamarck, Darwin a observat că toate formele de viață variază și, precum Lamarck, și-a dat seama că în rîndul indivizilor din generațiile care se succed cu rapiditate, trebuie să fie o luptă crîncenă pentru poziție sau existență. Variația și lupta sînt vizibile, cu deosebire, la plantele cultivate, iar Darwin a observat că grădinarul selectează ce este mai bun, prin aceasta „ameliorînd” rasa. „Văzînd că variațiile utile omului au apărut negreșit, se poate, aşadar, concepe ca fiind improbabil”, spune Darwin, „ca alte variații utile cumva fiecărei ființe, în marea și complexa luptă pentru viață, să fi apărut în cursul mai multor generații succesive? Dacă lucrurile se petrec astfel, ne putem îndoi (amintindu-ne că se nasc mai mulți indivizi decît este posibil să supraviețuiască) că indivizii avind asupra altora un avantaj, oricît de mic, ar avea cea mai bună șansă de a supraviețui și de a-și perpetua neamul? Această păstrare a diferențelor și a variațiilor individuale favorabile și distrugere a celor dăunătoare am numit-o Selecție Naturală sau Supraviețuirea Celui mai Adaptat”. Acesta este, așadar, darwinismul-factorul de control sau procesul în evoluție este selectiv: supraviețuirea, în cadrul

†Publicat în „The American Naturalist”, vol. 28, 1894, p. 661-678. Traducere de Francisc Gafton și Adina Chirilă. 
luptei pentru existență, a acelor indivizi care sînt cei mai potriviți pentru a supraviețui.

În vreme ce, însă, acesta este miezul curat al darwinismului, există variate ipoteze corelate sau incidentale care se leagă de el. De exemplu, Darwin a acceptat în oarecare măsură opiniile lui Lamarck în ceea ce privește importanța trăsăturilor funcționale; el a considerat că selecția sexuală, sau alegerea exercitată în cadrul asigurării împerecherii, este adesea un factor important în modificarea speciilor; el s-a gîndit că variația este indusă de modificările mediului, sau de „schimbarea condițiilor de viață”; el a crezut cu tărie în capacitatea de transmitere a trăsăturilor dobîndite. În jurul acestor două mari ipoteze-funcțională sau lamarckism, pe de o parte, și selectivă sau darwinism, de cealaltă-se învîrt în prezent, sub variate forme și modificări, discuțiile filozofice asupra naturii organice.

Înainte de a părăsi subiectul darwinismului, aş vrea să mă refer la opinia lui Darwin asupra cauzei variațiilor şi la credința sa în transmiterea trăsăturilor dobîndite. Trebuie să observăm că reabilitarea teoriilor lui Lamarck, sub numele de neo-lamarckism, are loc pe scară largă, cu scopul de a lega originea variațiilor de cauze externe sau de mediu, în opoziție cu cei care consideră sursa variației ca fiind esențialmente înnăscută sau cel puțin internă. Darwin însuşi a crezut că variația este indusă de mediu, iar factorul principal în acest mediu, cel puțin în ceea ce privește reacția sa asupra organismului, este probabil excesul de hrană, deși climatul și alte circumstanțe potrivnice sînt cauze puternice ale modificării. El a înşirat argumente pentru a sprijini „opinia că variațiile de orice fel și în orice grad sînt provocate în mod direct sau indirect de către condițiile de viață la care a fost expusă fiecare ființă și, în special, strămoșii ei” și că „fiecare variație în parte își are propria cauză determinantă”. Nu înțeleg cum s-a ajuns ca diferiți autori să declare că Darwin nu a crezut în mod explicit în cauzele externe ale variației, și se simt obligați să meargă înapoi la Lamarck spre a găsi o ipoteză care să susțină acest punct de vedere. Este adevărat că Darwin a crezut că natura sau direcția sau un anumit tip de variaţie dintr-o situație dată este determinată în mare măsură de constituţia organismului, dar variaţia în sine, adică variabilitatea, decurge în mare măsură din cauze externe, iar trăsăturile care se dezvoltă în timpul vieții unui individ pot deveni ereditare. $\mathrm{Cu}$ toate acestea, trebuie să spun că Darwin a recunoscut limpede importanța uniunii sexelor sau încrucișarea, ca pe o cauză a variației.

Crezînd Darwin că efectele variabilității decurg „în general, din schimbarea condițiilor care acționează de-a lungul generațiilor succesive”, el a crezut totodată că primul moment al schimbării-care apare la primul individ al unei serii date-poate fi transferat direct primului urmaș. El credea, adică, în transmiterea trăsăturilor dobîndite sau a noilor trăsături externe, fapt subliniat de convingerea sa că se pot transmite anumite mutilări şi chiar efecte ale utilizării și neutilizării. Cu toate acestea, deși Darwin a acceptat doctrina, el a socotit-o mult mai puțin completă decît a crezut-o Lamarck, ea fiind doar o parte incidentală a filozofiei sale, în vreme ce pentru lamarckism constituie un principiu esenţial.

Pînă acum nu a fost pus în discuție caracterul ereditar al tuturor trăsăturilor importante. $\mathrm{Cu}$ alte cuvinte, ereditatea a fost acceptată ca lege generală sau ca forță a lumii organice. O dată cu rafinarea discuțiilor, însă, a devenit necesar să se conceapă unele mijloace precise prin care ar trebui să acționeze transmiterea trăsăturilor sau a însuşirilor. De asemenea, s-a descoperit destul de repede că nici o filozofie a evoluției nu poate să se aştepte să explice fenomenele vieții organice dacă nu este conectată și coordonată cu o ipoteză a metodei eredităţii. Prin urmare, în vreme ce ipoteza eredităţii nu are nevoie în mod necesar să fie asociată cu teoria abstractă a evoluției, toate aceste ipoteze care stau astăzi în fața lumii științifice au ca obiect particular explicarea tendinţei progresive asumate de către formele de viață.

Este de neînțeles ca acel minuscul ou sau ovul fertilizat să trebuiască a reconstrui trăsăturile esențiale ale celor doi indivizi din care decurge, dacă nu cumva, în vreun fel, nu a derivat trăsături distincte din fiecare parte și organ al corpurilor părintești pe care le reproduce. Pare ca și cum ar fi de la sine o epitomă sau o condensare a strămoșilor săi, avînd puterea de a-și desfășura trăsăturile sau atributele pe parcursul întregii vieți a organismului căruia îi dă naștere. Au fost emise mai multe ipoteze care țin seamă de fenomenul eredității, printre care, una dintre cele mai importante, este tot teoria pangenezei lui Darwin. În mod provizoriu, Darwin a presupus că pe lîngă înmulțirea obişnuită a celulei, fiecare celulă poate „expulza granule minuscule care sînt dispersate prin întregul sistem; că acestea, atunci cînd li se furnizează nutriente corespunzătoare, se înmulțesc prin 
diviziune și în cele din urmă se dezvoltă în unități precum cele din care se trag". Aceste granule sau gemule au o afinitate naturală unele pentru altele și se adună laolaltă „din toate părțile sistemului” pentru a forma materialul sexual sau elementele sexuale. Prin urmare, aceste elemente sexuale care se unesc pentru a forma noul individ sînt un amestec rezumat al părinților. Mi se pare că valoarea acestei ipoteze stă nu atît în constituția și în comportamentul particular al acestor gemule, cît în faptul că încearcă să țină seamă de fenomenele cunoscute ale vieții presupunînd fiecare element corporat ca fiind reprezentat în elementele sexuale. Ipoteza nu a cîştigat niciodată sprijinul deplin, datorită presupusei improbabilități de existență fizică a gemulelor și a concentrării lor în sistemul sexual. Cu toate acestea, trebuie spus că o ipoteză mai simplă, care poate ține seama de fapte, încă nu a fost avansată, cu excepția cazului ipotezei ortogenetice a lui Cope, care presupune că fiecare celulă a corpului transmite germocelulelor „o modalitate de mișcare”.

Pentru scopul de față, însă, este nevoie să avem în vedere o altă ipoteză a eredității-avansată de către Weismann în 1883, care a dat naştere filozofiei numite acum neo-darwinism. Punctul de vedere al lui Weismann este interesant și unic. El se așează în pragul vieții organice și contemplă ce se petrece în cadrul reproducerii organismelor unicelulare. Aceste organisme se înmulțesc cel mai adesea prin diviziune simplă sau fisiune. Atunci cînd organismul atinge o anumită mărime, se contractă la mijloc și în cele din urmă se separă în două celule sau organisme. Este evident că un organism este geamănul celuilalt, nici unul nu este mai în vîrstă, nici unul nu este părinte, fiecare fiind părtaș la un stoc comun de protoplasmă. Protoplasma se divide iarăși în două organisme, care apoi se divid iarăși, și tot așa la infinit, putîndu-se spune că cel mai îndepărtat individ al seriei conține o parte din protoplasma originală; cu alte cuvinte, protoplasma este continuă. În măsura în care protoplasma este sediul sau baza fizică a vieții, se poate spune că organismul unicelular este nemuritor sau că nu cunoaște moartea naturală.

Totuşi, în timp intervine diviziunea munciicelule locuind împreună în colonii, anumite celule îndeplinind o funcție, iar alte celule alte funcții. Probabil că acesta a fost începutul organismelor pluricelulare, în care anumite celule au dezvoltat funcția specifică de reproducere sau în cele din urmă au de- venit elemente ale sexului. Pe măsură ce structura organismelor a devenit mai complexă, diferențele dintre porţiunea reproductivă sau gamet și partea învecinată sau porțiunea corpului au devenit tot mai mari. Weismann afirmă că aceste două elemente sînt diferite și distincte unul de altul în natura lor și că, în măsura în care organismele unicelulare își generează urmașii lor identici prin diviziune simplă, elementele reproductive ale corpului complex sau pluricelular trebuie să continue a-și perpetua neamul sau să se bucure de nemurire, în vreme ce toate celulele înconjurătoare ale corpului mor și se reproduc doar prin intermediul puterii reconstructive a celulelor sexuale. Conform acestei ipoteze, aşadar, există două elemente sau plasme în fiecare ființă organizată, germoplasma și soma-plasma sau plasma corpului, fiecare organism care procreează păstrîndu-și astfel germoplasma pentru generațiile viitoare, în vreme ce moartea distruge restul. Un punct vital al acestei ipoteze este metoda prin care soma-plasma sau organele și corpul organismului pot fi într-atît de influenţate de gameți încît pot deveni ereditare. La început se pare că o afirmație ca aceea a lui Darwin ar putea fi utilă aici-că germo-plasma este pătrunsă de particule aruncate din toate părțile sau de celule somatice. Weismann, însă, consideră că aceasta ar fi prea greoaie şi atribuie transferul acestor trăsături prin mediul germo-plasmei unor „variații ale constituției sale moleculare". Cu alte cuvinte, nu poate fi vorba despre moștenirea unei trăsături care și-ar avea originea la periferia individului, deoarece nu există mijloace de a-și transfera gameților felul de a fi. Orice modificare a urmaşilor este predeterminată în germo-plasmă, iar dacă un organism nou se modifică prin contactul cu agenții externi, o atare modificare se pierde o dată cu moartea individului. „Trăsăturile dobîndite doar prin acțiunea circumstanțelor externe manifestate în timpul vieții individului nu se pot transmite”. „Toate trăsăturile manifestate de către urmași se datorează schimbărilor primare din gameți”. Se admite că efectul continuu al mediului, care acționează din cînd în cînd, afectează în cele din urmă germo-plasma, însă nu în prima generație în care astfel de influențe străine pot fi exercitate. $\mathrm{Cu}$ alte cuvinte, trăsăturile dobîndite nu pot fi ereditare.

S-ar părea că, dacă această ipoteză exclude posibilitatea evoluției sau a modificărilor continui ale speciei, tot astfel ea nu acceptă modificările decurgînd direct din surse externe. Weismann, însă, pre- 
supune că variația-sau cel puțin orice variaţie care se află în uzul permanent al speciilor-se trage din unirea sexelor, în măsura în care, spre deosebire de germo-plasmă, doi indivizi se unesc și, din variațiile astfel induse, derivă materialul cu care orice selecție naturală lucrează în cadrul luptei pentru existență. „Sînt pe deplin convins”, scrie Weismann, „că creșterea nivelului de dezvoltare a lumii organice a devenit posibilă doar prin introducerea reproducerii sexuate". „Reproducerea sexuată a apărut prin și pentru selecția naturală, ca singurul mijloc prin care variațiile individuale pot fi unite şi combinate în orice proporție posibilă”.

Se va vedea că Weismann este un darwinistunul care crede în selecția naturală ca în singurul proces care controlează evoluția, dar spre deosebire de Darwin el se referă la variația de sex şi declară că nici o trăsătură nouă sau dobîndită, care își are originea în corpul organismului, nu se poate transmite. Mijlocul sau mașinăria întocmai, prin care presupune el că acționează ereditatea, este mai degrabă o chestiune embriologică decît una filozofică. Pe noi ne interesează cu deosebire acele rezultate ale sale-care sînt mărci distinctive ale neo-darwinismului-care susțin că variaţia este de origine sexuală sau internă și că trăsăturile dobîndite nu sînt ereditare.

În opoziție cu acest corp de credințe care, în special în Anglia, a fost susținut cu multă agresivitate, se află neo-lamarckismul, care se compune din lamarckism și darwinism, și care are adepți deosebit de puternici în America de Nord. Principiile proprii acestei filozofii sînt credința că mediul sau cauzele externe sînt direct responsabile pentru multe dintre variații și că, adesea, trăsăturile dobîndite sînt ereditare. Alte aspecte ale acesteia, prezente în grade diferite la persoane diferite, sînt credința în efectele transformatoare ale uzului şi ale lipsei de uz şi în selecția naturală.

Marele dezacord dintre neo-darwiniști şi neolamarckiști stă în controversa privitoare la transmisibilitatea trăsăturilor dobîndite, iar în prezent chestiunea aceasta a ajuns cu atîta vigoare în prim plan, încît s-au estompat alte diferențe dintre cele două ipoteze. Este demn de observat că darwinismul şi neo-lamarckismul mai întîi observă faptele sau fenomenele și apoi încearcă să le explice, în vreme ce neodarwinismul sau weismannismul mai întîi adoptă ipoteza și abia apoi încearcă să o demonstreze. Cred că oricine va fi izbit de această diferență de atitudine dacă citește capitolul lui Darwin asupra pangenezei și apoi citește capitolul lui Weismann asupra eredității. Neo-darwiniștii solicită zgomotos fapte sau probe cum că trăsăturile dobîndite sînt ereditare și încearcă să arunce povara probelor pe oponenții lor, în timp ce ei nu oferă probe pentru propria poziție și își încurcă adversarii cu subtilități verbale. Oricum, răspunderea probelor este, în mod evident, a neo-darwiniștilor, de vreme ce și-au asumat negarea fenomenelor care, pînă în acel moment, se considera a fi fost lămurite.

De-a lungul ultimilor cinci sau șase ani, între neo-darwiniști și neo-lamarckiști a apărut un număr mare de discuții polemice, dar oricare ar putea fi efectele acestora asupra vechii filozofii, pentru mine este limpede că la unele dintre atacurile asupra neodarwinismului nu se poate replica în nici o modalitate rațională și este sigur că acestea 1 -au obligat pe Weismann să-și schimbe poziția cu referire la unele dintre definițiile sale. Desigur, anumite etape ale acestei dezbateri ispitesc cu o forță aparte unele minți, în vreme ce asupra altora exercită o slabă influență. Obiecțiile mele față de neo-darwinismşi admit că înclinațiile mele sînt puternic îndreptate împotriva sa-îmi par a fi oarecum diferite de cele care i se aduc cel mai ades, și voi prezenta foarte pe scurt pe primele trei care mă influențează cel mai mult.

1. Nu pot vedea în non-transmisibilitatea trăsăturilor dobîndite o asumpție necesară pentru argumentele fundamentale ale lui Weismann. Deja am explicat raționamentul său din cazul reproducerii organismului unicelular. $\mathrm{Nu}$ pot verifica toate concluziile faptelor probabile pe care se întemeiază ipoteza sa. În treacăt trebuie spus că una dintre obiecțiile majore privind temeiul fundamental al teoriei este dificultatea de a deriva soma-plasma muritoare din germo-plasma nemuritoare, chestiune la care, totuşi, Weismann a dat un răspuns oarecum complet.

Atunci cînd organismele devin complexe, este necesar să se presupună că soma-plasma fie are, fie nu are o influență directă asupra germo-plasmei. Weismann a eliminat mai multe ipoteze care presupun că există o conexiune vitală și necesară între unitățile corpului și unitățile reproductive, iar apoi, pentru a evita dificultăţile pe care le-ar implica ereditatea trăsăturilor dobîndite, a presupus că astfel de trăsături nu sînt ereditare. Strădaniile sale ulterioare au fost folosite în mare parte pentru a arăta acest lucru. Această supoziție a fost făcută cu scopul de 
a simplifica ipoteza îndepărtînd greoaiele gemule ale lui Darwin și corpurile sau mișcările similare ale altor filozofi, prin urmare localizînd sediul germo-plasmei. Imediat, însă, el întîlnește dificultăți la fel de mari precum cele pe care le evită. În situațiile în care generațiile de organisme asexuate alternează cu cele sexuate, el trebuie să presupună că germo-plasma este unită cu soma-plasma şi este probabil, aşadar, să se distribuie în întreg organismul. „De fapt, pot fi situații în care” scrie Weismann, „o astfel de separație [a germo-plasmei de soma-plasmă] nu se petrece înainte ca animalul să fie pe deplin format, și altele, așa cum cred că am arătat, în care această separație apare la prima sau la a doua generație care urmează, adică în mugurii produși de către părinte”. El este forțat să admită că, în cazul begoniilor, care se înmulțesc prin frunze, germo-plasma este distribuită, probabil, prin frunziș. Același lucru trebuie recunoscut pentru toate plantele, deoarece toate se pot înmulți și modifica prin părți asexuate. Trebuie admis, apoi, că nu există germo-plasmă localizată în regnul vegetal și în unele cazuri nici în cel animal; dacă germo-plasma este distribuită pînă la periferia organismului, de ce nu poate fi ea afectată în mod direct de către mediu, precum soma-plasma? Sau de ce ipoteza este mai puțin criticabilă decît pangeneza lui Darwin, care presupune că fiecare unitate organică poate comunica cu germo-plasma?

După cum am spus, Weismann mai presupune că mijlocul prin care germo-plasma este capabilă să reconstruiască soma-plasma în urmași stă, printr-o modificare oarecare, în „constituția sa moleculară”, o presupunere care nu era nicicum nouă atunci cînd Weismann a proclamat-o. „Modalitatea exactă în care ne imaginăm diferențierea ulterioară a coloniei ca potențial prezentă în celula reproductivă”, scrie el, „devine o chestiune de importanță relativ mică. Ea poate consta într-un aranjament molecular diferit sau într-o schimbare oarecare a constituției chimice, sau se poate datora ambelor cauze, combinate". Oricum și-ar dobîndi germo-plasma influențele sale somatice, trebuie să existe o conexiune directă între cele două, și este destul de ușor să se prezume existența gemulelor ca și a oricărei influențe mai puțin perceptibile. $\mathrm{Nu}$ argumentez în favoarea pangenezei, doar enunț ceea ce mi se pare a fi o obiecție valabilă cu privire la construcția de bază a ipotezei lui Weismann, din teză fiind destul de lesne de presupus o interpretare sau alta, a procesului sau a mijloacelor eredităţii. Dacă există vreo conexiune vitală, de orice fel, între soma-plasmă şi germo-plasmă-după cum ipoteza în sine trebuie să admită—atunci de ce nu poate soma-plasma să influențeze germo-plasma în mod direct?

Încă o dată, aș vrea să subliniez faptul că modificarea și evoluția speciilor vegetale poate avea loc pe deplin fără interpunerea sexului, adică prin propagare prin butași sau răsaduri ale diferitelor părți. Lucrul acesta dovedește una din două: că germo-plasma nu este necesară speciilor sau că aceasta nu este localizată, ci distribuită în întreg corpul individului, după cum am arătat mai sus; mi se pare că fiecare latură a acestei dileme îi este fatală lui Weismann. Dacă germo-plasma nu este necesară pentru reproducere, atunci trebuie eliminată ipoteza continuității germoplasmei; dacă germo-plasma este distribuită în întreaga plantă, atunci sîntem obligați să admitem că ea nu este localizată în gameți, dincolo de raza de acțiune a influențelor externe directe.

Înmulțirea sexuată a plantelor a fost adusă în atenția lui Weismann de către Strasburger, care a citat cazul înmulțirii prin frunze a begoniilor şi a spus că plantele înmulțite asexuat produc ulterior flori și semințe sau dezvoltă germo-plasmă. Weismann înfruntă obiecția presupunînd că este posibil pentru „toate nucleele somatice să conțină o fracțiune minusculă de germo-plasmă neschimbată”, dar se pare că el consideră begonia a fi o excepție față de cele mai multe plante, întrucît declară că „nimeni nu a crescut vreodată un copac dintr-o frunză de tei sau de stejar, sau o plantă cu flori dintr-o frunză de lalea sau de rochița-rîndunicii”. Henslow satisface această ultimă declarație spunînd că acest lucru nu a fost realizat pur și simplu deoarece „niciodată nu a meritat să se facă aşa ceva. Totuşi, dacă s-ar oferi un premiu pentru lalele sau stejari crescuți din frunze tăiate, în curînd ar apărea o mulțime”. Ceea ce dorește Weismann să arate este că begonia este o excepție față de alte plante, prin aceea că permite înmulțirea prin frunze tăiate, deși ar putea să știe că sute de plante pot fi înmulțite în acest fel, și că-ceea ce duce către același lucru—toate plantele se pot înmulți prin părți asexuate, precum tulpini sau rădăcini.

Aici, însă, există un alt aspect al acestei înmulțiri asexuate a plantelor, pe care nu-mi amintesc să îl fi văzut menționat în acest sens. S-a spus că plantele apărute în urma înmulțirii asexuate pot produce flori ulterior, și pot relua metoda normală de reproducere și variație. Aș dori să adaug ceea ce am spus deja, că 
plantele se pot înmulți asexuat încontinuu şi cu toate acestea urmașii pot varia, iar variațiile se pot transmite de la o generație la alta, la fel ca în cazul în care ar fi intervenit producția de semințe. Lucrul acesta $s$-a adeverit în cazul anumitor plante de-a lungul unei perioade lungi de timp, precum în cazul bananeiși orice grădinar informat știe că plantele înmulțite prin tăiere repetată „se distrag” sau variază. Așadar, există situații în care variația nu își are originea în sex, dacă nu cumva Weismann este dispus să accepte că rezultatul uniunii sexuale precedente a rămas latent de-a lungul unui anumit număr de generații și a fost purtat în toate părțile plantei de o germo-plasmă difuzată peste tot; dacă admite acest lucru, atunci va trebui să insist din nou că această germo-plasmă trebuie să fie la fel de maleabilă la influențele externe precum soma-plasma cu care este indisolubil legată. Am repetat acest argument pentru a introduce tema „mugurelui de variații” sau acele „distracții” care din cînd în cînd apar pe anumite membre sau părți de plante și care aproape întotdeauna sînt lesne de propagat prin tăiere. În cadrul aplicării normale și legitime a ipotezei weismanniene, aceste variații nu pot fi atribuite sexului. Deși aceste „distracțiï” sînt bine cunoscute horticultorilor, în general ele sînt socotite a fi rare, însă nimic nu este mai departe de adevăr. De fapt, fiecare ramură a copacului este diferită de fiecare altă ramură, iar cînd diferența este suficientă pentru a atrage atenția sau pentru a avea o valoare comercială, ea este propagată și numită „distracție”. Lucrul acesta mă face să îmi reamintesc vechea discuție despre fitomer sau ipoteza că fiecare nod sau internod al unui copac - putem adăuga și rădăcinileeste, în realitate, un individ distinct în măsura în care deține capacitatea de a duce o existență independentă atunci cînd este separat de plantă, și de a-și reproduce propria natură. Oricît ar putea fi acesta un subiect de speculații, este cu siguranță adevărat în ceea ce privește fenomenul și arată în mod concludent că dacă germo-plasma există, ea există prin întreaga structură a plantei. Această concluzie este inevitabilă și din alt considerent: în orice moment dinainte de înflorire, plantele sînt organisme asexuate, totodată, germoplasma trebuind păstrată împreună cu soma-plasma. Această concluzie, însă, nu se potrivește cu weismannismul aşa cum este el propovăduit în prezent, și numai acest lucru are trebui să mă facă să elimin ipoteza pentru plante, oricît de bine s-ar aplica ea la regnul animal.
Henslow a adus un argument diferit pentru a arăta că germo-plasma plantelor poate fi expusă în mod direct la influența externă (Origin of Floral Structures). Se presupune că germo-plasma ar fi situată în floare, iar celula-ou din embrio-sac și celulasămînţă din grăuntele de polen sînt aproape de suprafață, fiind în mod direct afectate de interferența cu albinele și cu alți stimuli externi. Henslow se străduiește să arate „că infinita varietate a adaptărilor la insectele care pot fi descoperite în flori poate rezulta din acțiunea directă a insectelor înseși, conjugată cu excitabilitatea protoplasmei”. Aceste trăsături trebuie să fie parţial dobîndite de-a lungul vieții unui individ dat.

2. De asemenea, mi se pare că prezumția, pe baze filozofice generale, este împotriva doctrinei că influențele externe imediate sînt lipsite de efect permanent. Dacă admitem — aşa cum fac toți filozofiică speciile sînt variabile și că formele de viață s-au modelat în relație cu adaptările lor la mediu, atunci sîntem îndreptățiți să presunem că fiecare schimbare din mediu trebuie să trezească un răspuns vital în specii. Dacă nu urmează acest răspuns, atunci mediul este lipsit de influență asupra organismului; sau dacă el urmează dar nu este transmis, el este de asemenea pierdut, iar mediul este neputincios. Nu are importanță dacă, împreună cu neo-darwiniștii, presupunem că acest efect nu devine ereditar pînă cînd gametul nu este afectat-adică pînă cînd două sau mai multe generații au trăit sub presiunea mediului-, totuşi trebuie să rezulte că schimbarea trebuie să fi avut un început definit în timpul vieții individului, deoarece este imposibil să se conceapă că schimbarea îşi are originea în două generații. Cu alte cuvinte, începutul este singular, două generații înseamnă plural. Fie că modificarea este vizibilă în mod direct în corpul organismului, fie că o forță intangibilă influențează gametul, aceasta este nu mai puțin o trăsătură de mediu, și, iniţial, fost dobîndită. Dacă acest lucru nu este adevărat-că condițiile de viață schimbate exercită un efect direct asupra filogeniei speciiloratunci nici o variație nu poate fi păstrată, ceea ce vine din recombinarea elementelor sexuale originale sau ancestrale, iar problema felului în care aceste elemente sexuale și-au dobîndit diferența inițială tot ar rămîne nerezolvată.

Neîndoios că neo-darwiniștii ar înlătura acest argument spunînd că ipoteza lor admite pe deplin importanța acestor influențe externe, singura rezervă 
fiind că acestea trebuie să afecteze gametul. Este drept că aceasta este o cale de scăpare comună, dar nu poate fi negat faptul că tăgăduirea influenței forțelor externe sau de mediu este cu adevărat diferența fundamentală dintre aceștia și darwiniști sau neolamarckiști, precum o va arăta următoarea notă din Weismann: „Obiectivul nostru este de a decide dacă schimbările din soma (corp, opus gameților) care s-au produs prin acțiunea directă a influențelor externe, inclusiv uzul și lipsa lui, pot fi transmise; dacă acestea pot influența gameții în așa fel încît mai tîrziu vor provoca apariția spontană a unor schimbări corespunzătoare la nivelul generației viitoare. Aceasta este chestiunea care impune un răspuns și, așa cum s-a arătat mai sus, un astfel de răspuns ar hotărî dacă principiile lamarckiene de transformare trebuie reținute sau abandonate".

Dacă, aşadar, pentru a repeta, organismele sînt adaptate la mediile lor, trebuie să fie deopotrivă valabil faptul că acest mediu își afectează direct locuitorii. Avînd în vedere intensa luptă pentru existență, căreia toate organismele i se supun, este foarte probabil ca orice variație avantajoasă să poată fi păstrată la un moment dat. Nu pot concepe ca natura să-și permită să piardă rezultatul vreunui efort.

3. A treia mea convingere împotriva neodarwinismului vine din faptul că avocații săi înlătură în mod constant argumentele oponenților lor prin mistificări verbale și definiții ingenioase. Această cale este atît de frecvent urmată, iar faptul este atît de bine cunoscut, încît pare aproape inutil să mă refer la ea aici; și totuşi, există unele aspecte pe care nu mă pot opri de la a le menționa.

Weismann declară că folosește sintagma trăsătură dobîndită în sensul ei original. După cum am văzut, această sintagmă, sau cel puțin ideea, a fost folosită mai întîi de către Lamarck, care a folosit-o întocmai sau un echivalent pentru a desemna 'orice schimbare dobîndită de către un organ în urma unui exercițiu uzual, suficient încît să provoace acea schimbare'. În fapt, baza filozofiei lui Lamarck este presupunerea caracterului ereditar al trăsăturilor care decurg în mod direct din uz sau din lipsa acestuia, această idee a sa cu privire la o trăsătură dobîndită fiind, aşadar, una care apare în timpul vieții unui individ, datorită vreunei cauze determinante externe. La Darwin, chiar dacă mai puțin limpede definită, noțiunea era esențialmente aceeași, iar acesta a adunat o masă de dovezi pentru a arăta că astfel de trăsături sînt transmisibile, el chiar mergînd mai departe decît Lamarck, prin incercarea de a arăta că mutilările pot fi ereditare. Definiția timpurie a lui Weismann pentru trăsăturile dobîndite este destul de limpede. Astfel de trăsături, adică somatogenice, „nu doar includ efectele mutilărilor, dar și schimbările ce decurg din performanțe crescute sau diminuate ale funcției, și cele care se datorează în mod direct nutriției și oricăror altor influențe externe care acționează asupra corpului”. Raportîndu-ne corect și cinstit la această definiție este destul de ușor să o respingem, adică să arătăm că unele trăsături astfel dobîndite sînt ereditare. Dovezile momentului, însă, sînt avansate, definiția este sumară, iar neo-darwiniștii declară că o trăsătură dată a fost potențial prezentă în gameți și nu a fost supraindusă în prealabil de condițiile externe-o poziție care, atît timp cît se permite nedemonstrarea, nu poate fi nici respinsă. $\mathrm{O}$ vacă își pierde cornul stîng ca urmare a supurației, iar doi dintre vițeii ei au coarne rudimentare, dar Weismann spune imediat: „Pierderea unui corn al vacii poate veni dintr-o malformație congenitală”. Cu siguranță! și poate să nu vină de acolo; presupunerea fiind că nu. Un soldat își pierde ochiul stîng ca urmare a unei inflamații, iar doi dintre fiii săi au ochiul stîng imperfect. „Soldatul”, spune Weismann, „nu și-a pierdut ochiul stîng deoarece a fost rănit, ci întrucît a fost predispus de la început să se îmbolnăvească, și lesne s-a inflamat după o leziune ușoară”! Această manieră gratuită de a respinge cazurile înregistrate de presupuse transmiteri de mutilări şi a altora de acest gen este comună la neo-darwiniști, însă o socot a fi greoaie și forțată. În măsura în care este incapabilă de a proba-și nimic nu trece dincolo de simpla enunțare a ipotezei asumate-, cu greu ar putea fi luată în seamă. Ar fi cu mult mai bine pentru neo-darwiniști dacă ar refuza în mod deschis declarațiile privitoare la transmiterea mutilărilor, decît să încerce explicarea insidioasă a acestora, deoarece încă este foarte îndoielnic că situațiile care au fost înregistrate, ale unor asemenea transmiteri, vor rezista la investigarea atentă.

Poate că, totuşi, cel mai remarcabil exemplu din această specie de logică neo-darwinistă este dat de Weismann atunci cînd este cu putere presat de către Hoffmann, care presupune că a dovedit ereditatea anumitor trăsături dobîndite la căței. Weismann spune: „De vreme ce trăsăturile despre care vorbește Hoffmann sînt ereditare, termenul nu li se poate aplica corect"; în felul acesta arată că concepția sa fun- 
damentală asupra trăsăturii dobîndite este că ea nu poate fi transmisă! Apoi trece la elaborarea următoarei definiții: „Nu m-am îndoit niciodată de transmiterea schimbărilor care depind de o alterare în germoplasmă a celulelor reproductive, totdeauna susținînd că aceste schimbări, și numai acestea, trebuie să se transmită". Apoi continuă spunînd că este necesar să existe „doi termeni care disting cu precizie între cele două grupe de trăsături-trăsăturile primare, care apar mai întîi în corp, și unele secundare, care își datorează apariția variațiilor din gameți, oricum ar fi apărut acestea. Ne-am obișnuit pînă acum să le numim pe primele trăsături dobindite, dar le putem numi deopotrivă somatogenice, deoarece decurg din reacția somei la factorii externi, în vreme ce toate celelalte trăsături le pot fi opuse sub denumirea blastogenice, deoarece ele includ toate acele trăsături ale corpului care au apărut din schimbări petrecute în gameți. (...) Susținem că trăsăturile somatogenice nu pot fi transmise sau, mai curînd, că aceia care susțin că acestea pot fi transmise trebuie să furnizeze dovezile necesare”. Adică: schimbările din soma-plasmă nu se transmit; trăsăturile dobîndite sînt schimbări în soma-plasmă, prin urmare caracterele dobîndite nu pot fi transmise! Or, pentru a folosi fraza scurtă a lui Weismann, „De vreme ce trăsăturile (...) sînt ereditare, termenul [dobindit] nu poate corect fi aplicat acestora!” Cu siguranță că neo-darwinismul este inexpugnabil!

În mod incontestabil, weismannismul a făcut multe pentru a lămuri unele dintre cele mai încîlcite probleme ale biologiei, și a curățat vechile ipoteze de multe dintre cele socotite bolnave sau false. El a pus la încercare credințe care fuseseră prea lesne acceptate. Importanța sa pentru știința eredității în zona ei biologică este acceptată, iar explicația sa în ceea ce privește rolul sexului este una dintre cele mai bune contribuții la filozofia naturii organice. Poate că a suferit de pe urma unor adepți prea înflăcărați, iar marea sa slăbiciune stă în refuzul încăpăţînat de a accepta o clasă importantă de fenomene asociate cu trăsăturile dobîndite, o explicație suficientă care, cred eu, poate fi însușită fără violență față de ipoteză.

Cei mai mulți neo-lamarckiști acceptă multe dintre învățăturile lui Weismann. În vreme ce, însă, prin comparație, sînt puțini cei ce acceptă că mutilările sînt direct transmisibile, convingerea generală și puternică este că multe dintre trăsăturile cu adevărat dobîndite sînt ereditare, şi se pare că există dovezi care demonstrează acest lucru. De asemenea, în vreme ce variația sexuală este pe deplin acceptată, în mod logic decurge că trăsăturile dobîndite sînt ereditare, că o cantitate mare a variațiilor se datorează în mod direct cauzelor externe. Poate că deprinderea de a gîndi a celor mai mulți darwiniști și neo-lamarckiști este ceva precum:

Toate formele de viaţă sînt variabile. Variația procură materialul din care decurge orice progres. Variația se datorează uniunii sexuale, schimbării condițiilor de viață, panmixiei sau încetării selecției naturale și, probabil, întrucîtva uzului direct și lipsei de uz. Există o luptă intensă pentru existență. Toate formele sau variațiile folositoare speciilor tind să trăiască, iar cele mai dăunătoare tind să fie distruse pe calea acțiunii agentului simplu care este selecția naturală. Aceste forme nou apărute tind să devină permanente, uneori imediat, dar cu cît mediile de transformare sînt mai prezente, cu atît mai mare este, în ansamblu, probabilitatea ca modificările rezultate să persiste. 